Journal of Science
http://dergipark.gov.tr/gujs

\title{
Bromination of 1,2-Dimethylenecyclohexane: Temperature Effect on Product Distribution
}

\author{
Aliye ALTUNDAS ${ }^{1, *(1)}$ \\ ${ }^{I}$ Faculty of Science, Department of Chemistry, Gazi University, 06500 Ankara, Turkey
}

Highlights

- The bromination reactions of 1,2-dimethylcyclohexane were examined.

- The reaction temperatures and the amount of the bromine affected the product distributions.

- As the temperature increased, it caused a decrease in the amount of kinetically controlled product

- The rise in temperature led to an increase in radicalic addition products.

- Increasing the amount of bromine produced an increase in the amounts of radicalic addition products.

\section{Article Info}

Received: 02/10/2018 Accepted: 12/11/2018

\section{Keywords}

Bromination 1,2Dimethylenecyclohexane High temperature bromination Radicalic addition

\begin{abstract}
In this study the electrophlic addition of bromine to an exocyclic diene, 1,2 dimethylenecyclohexane, was investigated. The bromination of 1,2-dimethylenecyclohexane yielded 1,2-bis(bromomethyl)cylohex-1-en at low temperature. Nevertheless, the bromination of 1,2-dimethylenecyclohexane at room temperature gave 1,4 addition product 1,2-bis(bromomethyl)cylohex-1-en as a main product together with 1-bromo-1(bromomethyl)-2-methylenecylohexane and 3-bromo-1,2-bis(bromomethyl)cyclohex-1-ene. Similarly, high temperature bromination of 1,2-bismethylenecyclohexane gave the radical bromination products (3-bromo-1,2-bis(bromomethyl)cyclohex-1-ene and 3,6-dibromo-1,2bis(bromomethyl)cyclohex-1-ene) in addition to the 1,4 addition product. While the bromination of exocylicdiene at room temperature with excess bromine gave tetrabrominated product 1,2-dibromo-1,2-bis(bromomethyl)cyclohexane as a sole product, the bromination of exocyclicdiene in high temperature with excess bromine resulted in a tetra brominated product 1,2-dibromo-1,2-bis(bromomethyl)cyclohexane and the three brominated product 3-bromo-1,2-bis(bromomethyl)cyclohex-1-ene together with the radicalic tetrabrominated product 3,6-dibromo-1,2-bis(bromomethyl)cyclohex-1-ene as main products. However, the high temperature bromination of 1,4 brominated product with excess bromine provided only the radicalic brominated product 3-bromo-1,2bis(bromomethyl)cyclohex-1-ene and 3,6-dibromo-1,2-bis(bromomethyl)cyclohex-1ene.Thus the functional agents which can be used as starting material in the synthesis of many compounds were synthesized, purified and characterized.
\end{abstract}

\section{INTRODUCTION}

Cyclic dienes such as 1,2-dimethylenecyclohexane (1) and 1,2-dimethylenecyclopentane (2) have attracted interest because their production of multicyclic adducts which are used as a starting material to synthesize of many natural products by using the Diels Alder reaction and electrophilic addition of their conjugated double bonds (Figure 1) [1-9].<smiles>C=C1CCCCC1=C</smiles>

1

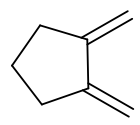

Figure 1. 1,2-Dimethylenecyclohexane (1) and 1,2-dimethylenecyclopentane (2) 
Brominated compounds, which are used as intermediates in the synthesis of many compounds, have synthetic importance as a starting material. One of the well known reactions of unsaturated compounds is formally the addition of bromine to the carbon-carbon double bond [10,11]. The structure of the addition of the intermediates is related to the structure of the substrate and the reaction medium. As a matter of fact previous studies have shown that the temperature of the reaction has a dramatic effect on product distribution [12-16].

The intermediates, bridged bromonium ions, take part in the bromination reaction of non-conjugated olefins that produce anti-adducts. However, the bromination of unsaturated bicyclic systems gives way to the rearrangements of the molecular skeleton. For instance, the electrophilic addition of bromine to oxabenzonorbornadiene (3) causes the rearranged product formation of dibromoaldehyde $\mathbf{4}$ in high yield (Figure 2) [17].

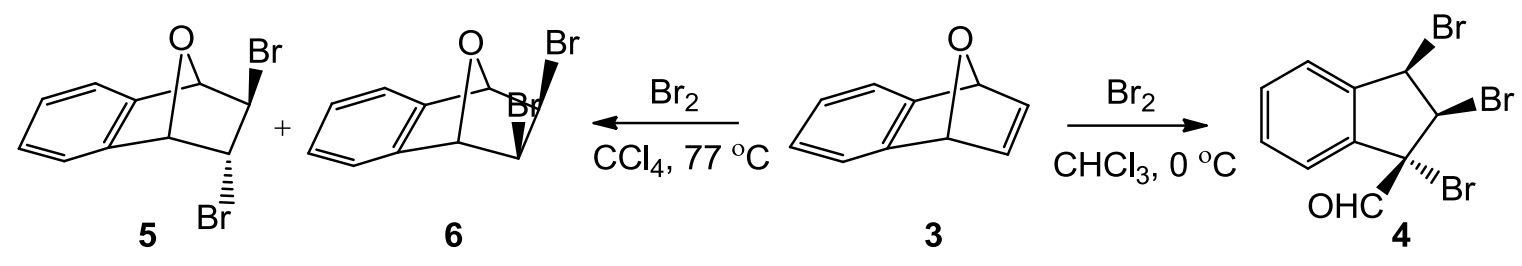

Figure 2. Bromination reactions of oxobenzonorbornadiene

If electrophilic addition is carried out on a compound having nonconjugated dienes, the product frequently obtained is a 1,2-addition. In the conjugated system, the 1,4-addition product is the most stable one as regards the thermodynamically controlled product, and it becomes dominant. Most of the times, when the reaction conditions exist, the 1,2-addition product turns into a mixture of 1,2- and 1,4-addition products which is full of 1,4-addition product [18].

Electrophilic additions of bromide to conjugated dienes usually contain allylic cations which have bromine as intermediates. Bromide found in the reaction medium can enter into a reaction with a nucleophilic from any of its positive centers to produce 1,2-addition and 1,4-addition products, in turn. The effect of temperature on product distribution is one of the most interesting properties of electrophilic addition reaction of conjugated dienes. When the reaction is carried out in different temperatures, usually the 1,2-addition product is present in higher amounts at lower temperatures while the more 1,4-addition product is formed at higher temperatures [18].

The bromination of bicyclic molecule 7 at different temperatures yielded interesting results. In contrast to acyclic systems in the low-temperature $\left(0{ }^{\circ} \mathrm{C}\right)$ bromination of 7 , the 1,2-adduct was more stable and formed in greater amounts than the 1,4-adduct as a thermodynamically controlled product (Figure 3). Since the 1,4-adduct increases the ring strain in the molecule, the exocyclic double bond formation with 1,2-addition is more stable and preferentiall [19].

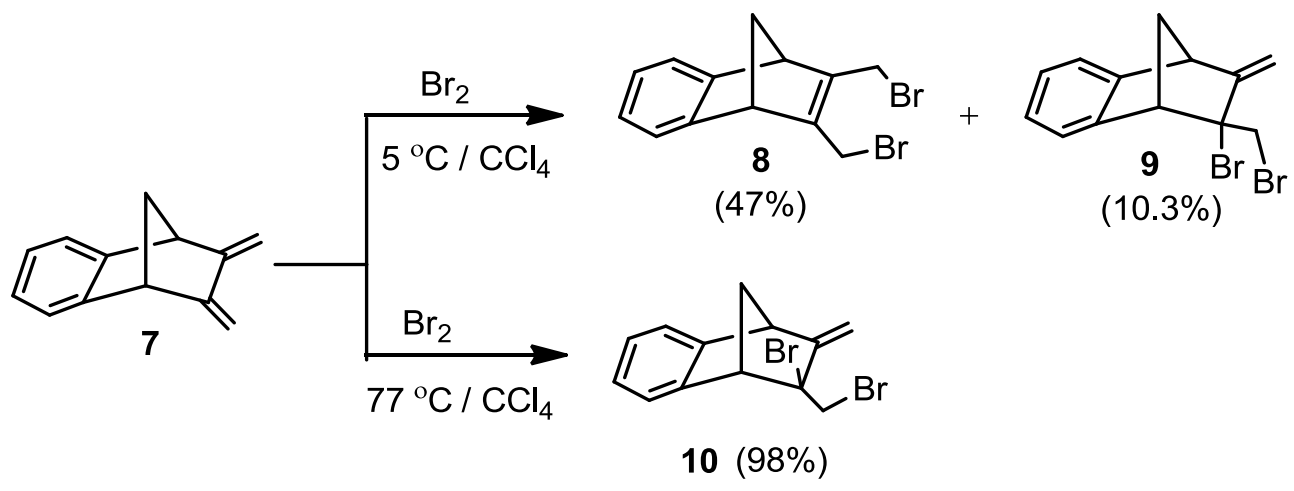

Figure 3. Products distributions of the brominotion of exocylicdiene 7 under the several reaction conditions 


\section{RESULTS AND DISCUSSIONS}

First 1,2-dimethylenecyclohexane (1) was synthesized beginning from cis-1,2-cyclohexanedicarboxylic anhydride in three steps as reported in the literature (Figure 4) [5].

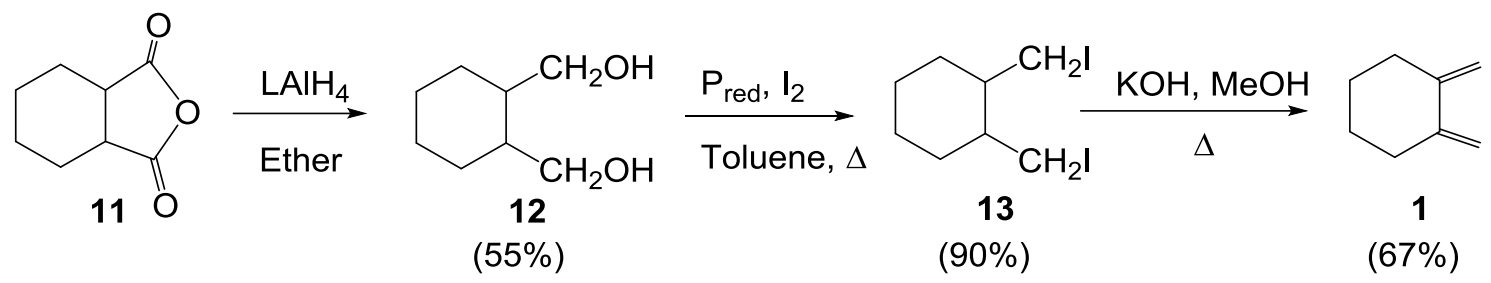

Figure 4. Synthesis of exocyclicdiene (1)

It was determined by ${ }^{1} \mathrm{H}-\mathrm{NMR}$ spectroscopy that the low temperature bromination of compound (1) in $\mathrm{CCl}_{4}$ constituted mainly two products.

After the mixture was processed through a thin layer chromatography which is on silica gel, only product 14 was isolated at 50\% yield (Figure 5). In the literature Schmidt and co-workers implied that while synthesizing disulfide, thioester and thiophene derivatives; 1,2-dimethylenecyclohexane reacted with bromide at room temperature gave 14, a pale yellow and eye watering liquid [20].

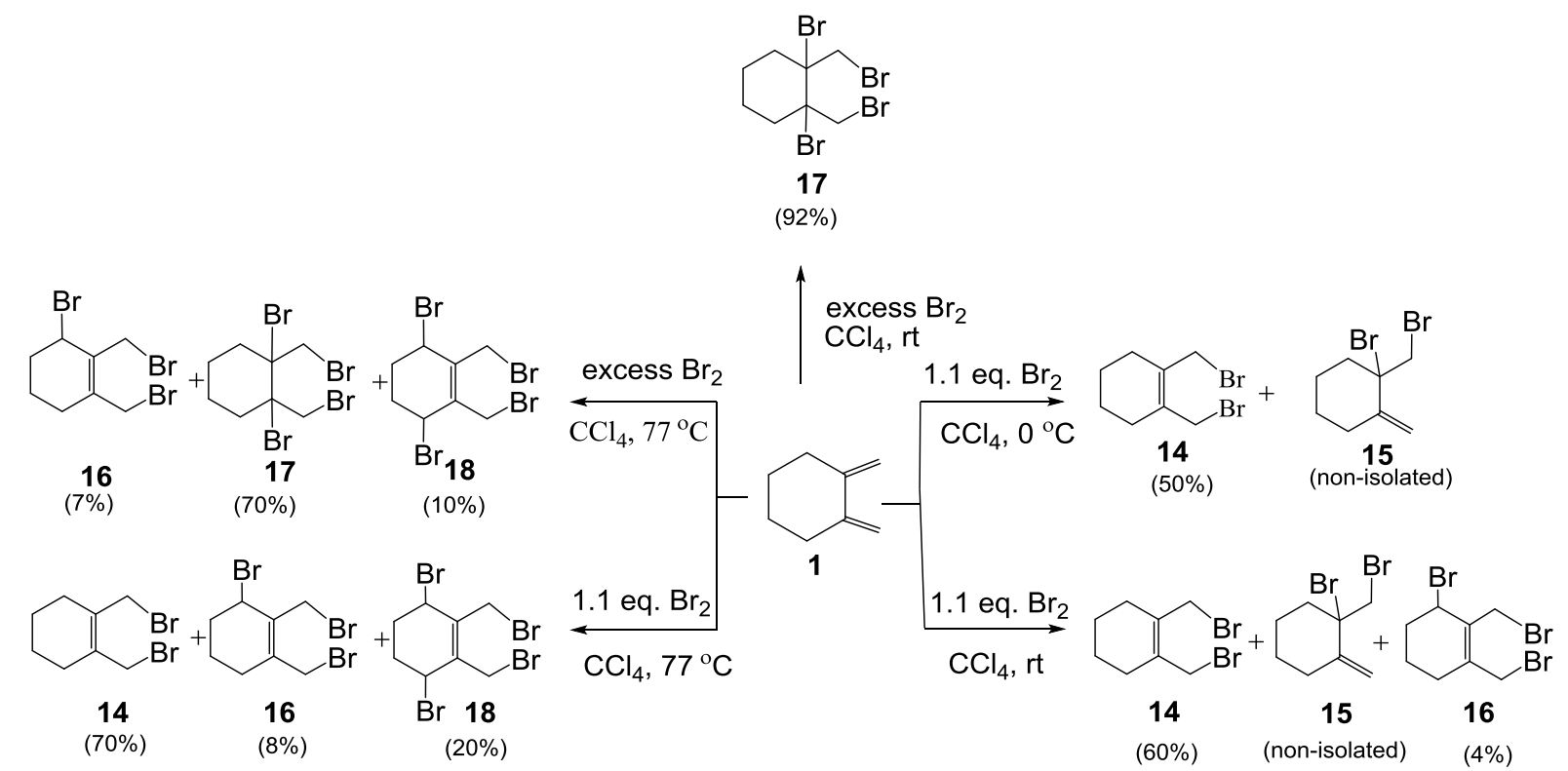

Figure 5. Bromination reactions of exocyclicdiene 1 under different reaction conditions

The structure of product $\mathbf{1 4}$ was primarily identified with ${ }^{1} \mathrm{H}$ and ${ }^{13} \mathrm{C}$ HMR spectra. The ${ }^{1} \mathrm{H}$ NMR spectra show three signals: $\delta 4.00,2.20,1.70 \mathrm{ppm}$. The signal at $\delta 4.00 \mathrm{ppm}$ is characteristic to methylene $\left(\mathrm{CH}_{2} \mathrm{Br}\right)$ protons. In the ${ }^{13} \mathrm{C}$ HMR spectra, the signals at $\delta 134.3,31.8,28.5,22.4 \mathrm{ppm}$ cooperated with structure symmetry.

At room temperature the bromination of 1,2-dimethylenecyclohexane (1), a solution of bromine in carbon tetrachloride was added in one portion to a stirring solution of $\mathbf{1}$ in carbon tetrachloride. After the removal of the solvent at low temperature, the ${ }^{1} \mathrm{H}$ NMR spectra of the reaction mixture were taken. The analysis of the crude product by ${ }^{1} \mathrm{H}$ NMR spectroscopy produced those three compounds. After the mixture was processed through a thin layer chromatography which is on silica gel, two products which are product $\mathbf{1 4}$ and compound 16 were isolated at ratios 60 and 4, respectively (Figure 5).

The structure of compound 16 was elucidated by ${ }^{1} \mathrm{H}$ NMR and ${ }^{13} \mathrm{C}$ NMR spectra analysis. The $200 \mathrm{MHz}$ 
${ }^{1} \mathrm{H}$ NMR shows the presence of one vinylic proton at $\delta 5.00$ and two AB systems between $\delta$ 4.20-3.80. The eight signals in the ${ }^{13} \mathrm{C}$ NMR spectrum are consistent with the asymmetry in the molecule.

Furthermore, the high temperature bromination of 1,2-dimethylenecyclohexane (1) was examined at 77 ${ }^{\circ} \mathrm{C}$. The hot bromine solution which is in $\mathrm{CCl}_{4}$ was poured directly into a refluxing solution of $\mathbf{1}$ in $\mathrm{CCl}_{4}$ at $77{ }^{\circ} \mathrm{C}$. The ${ }^{1} \mathrm{H}$ NMR analysis of reaction mixture showed that this solution was consisted of three products. After the crystallization and column chromatography, it was possible to separate three compounds, 14, 16, and 18 from each other. Compound 18's structure was characterized by ${ }^{1} \mathrm{H}$ and ${ }^{13} \mathrm{C}$ NMR spectrum data. The ${ }^{1} \mathrm{H}$ NMR spectra of compound 18 set forth an $\mathrm{AB}$ system and $\mathrm{AA}$ 'XX' coupling pattern arises from methylene $\left(\mathrm{CH}_{2} \mathrm{Br}\right)$ and ring methylene protons. A ${ }^{13} \mathrm{C}$ NMR spectrum of $(\mathbf{1 8})$ is highly symmetrical with regard to the symmetry in the molecule. Particularly, at $\delta 51.4,48.8,28.0,27.9$ ppm the four-line ${ }^{13} \mathrm{C}$ NMR spectrum of $\mathbf{1 8}$ is completely in harmony with $\mathbf{1 8}$.

Furthermore, the bromination of 1 with excess bromine produced only tetra bromine $\mathbf{1 7}$ in $92 \%$ isolated yield at room temperature. The structure of 17 was determined by ${ }^{1} \mathrm{H}$ NMR and ${ }^{13} \mathrm{C}$ NMR spectroscopy. The ${ }^{1} \mathrm{H}$ NMR spectra of $\mathbf{1 7}$ exhibit $\mathrm{AB}$ system arising from the bromomethylene group $\left(\mathrm{BrCH}_{2} \mathrm{Br}\right)$ which clearly indicates the addition of four bromine atoms to molecule 1 (Figure 5).

In order to carry out the high temperature bromination reaction of 1 with excess bromine; a hot solution of excess bromine in $\mathrm{CCl}_{4}$ was added to a refluxing solution of 1 in $\mathrm{CCl}_{4}$.

The analysis of the crude product showed that the 1,4-addition product was not formed but tetra bromide 17 and radical bromination product 16, 18 and a small amount of unidentified aromatic compound were produced. The compounds were purified with column chromatography on silica gel (Figure 6).

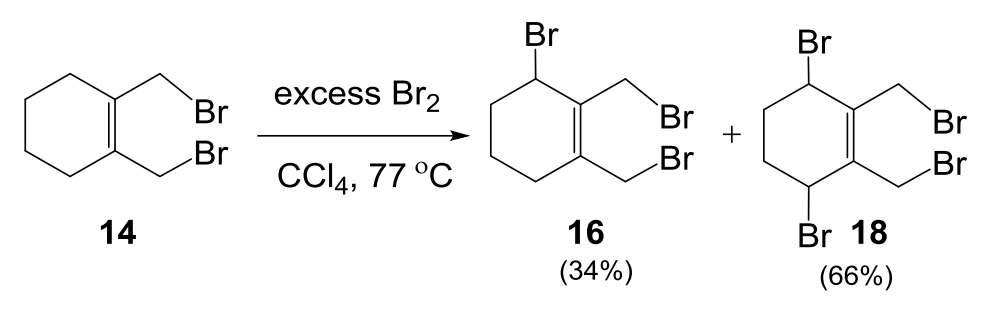

Figure 6. Bromination of 1,2-bis(bromomethyl)cyclohex-1-ene

\section{EXPERIMENTAL}

\subsection{General}

Melting points are not corrected. Infrared spectra were obtained from films on an $\mathrm{NaCl}$ plate for liquids and from a solution in $0.1 \mathrm{mmcell}$ or $\mathrm{KBr}$ pellets for solids on a regular instrument. Nuclear Magnetic Resonance $\left({ }^{1} \mathrm{H}\right.$ and $\left.{ }^{13} \mathrm{C}\right)$ spectra were recorded on $400(100) \mathrm{MHz}$ spectrometers. Elemental analysis was determined on a Leco CHNS-932 instrument (Ataturk University/Erzurum). Column chromatographic separations were performed on silica gel (60-mesh, Merck). Thin Layer Chromatography was performed by using Merck $0.2 \mathrm{~mm}$ silica gel 60 F254 analytical aluminum plates.

\subsection{Synthesis}

\subsubsection{Bromination of 1,2-Dimethylenecyclohexane (1) with 1 Equivalent Bromine at $0{ }^{\circ} \mathrm{C}$}

To a magnetically stirred solution of $1\left(108 \mathrm{mg}, 1.10^{-3} \mathrm{~mol}\right)$ in $1 \mathrm{ml}$ of $\mathrm{CCl}_{4}$ was added drop wise a solution of bromine $\left(160 \mathrm{mg}, 1.10^{-3} \mathrm{~mol}\right)$ in $1 \mathrm{ml} \mathrm{CCl}_{4}$ at $0{ }^{\circ} \mathrm{C}$. After the completion of the addition the resulting solution was stirred for $5 \mathrm{~min}$. The solvent was evaporated. Product 1,2bis(bromomethyl)cylohex-1-en (14) was isolated by TLC eluting with hexane $\left(\mathrm{R}_{\mathrm{f}} 0.65\right)$ and crystallized from $\mathrm{MeOH}(50 \%$ yield, $134 \mathrm{mg}$, colorless crystals melting at room temperature). Anal. Calcd for $\mathrm{C}_{8} \mathrm{H}_{12} \mathrm{Br}_{2}$ : C, 35.85; H, 4.51. Found: C, 35.89; H, 4.48.

For (14); 
${ }^{1} \mathrm{H}$ NMR $\left(\mathrm{CDCl}_{3}\right) \delta: 4.00(\mathrm{~s}, 4 \mathrm{H}) ; 2.20(\mathrm{~m}, 4 \mathrm{H}) ; 1.70(\mathrm{~m}, 4 \mathrm{H}) \mathrm{ppm} .{ }^{13} \mathrm{C} \mathrm{NMR}\left(\mathrm{CDCl}_{3}\right) \delta: 134.3,31.8$, 28.5, 22.4 ppm. vmax (liquid film): 2861, 2841, 2826, 1645, 1612, 1459, 1426, 1208, 617, $578 \mathrm{~cm}^{-1}$.

\subsubsection{Bromination of 1,2-Dimethylenecyclohexane (1) with 1 Equivalent Bromine at Room Temperature}

To a magnetically stirred solution of $1\left(200 \mathrm{mg} 1.8510^{-3} \mathrm{~mol}\right)$ in $3 \mathrm{~mL} \mathrm{CCl}_{4}$ was added drop wise to the solution of bromine $\left(270 \mathrm{mg}, 1.6810^{-3} \mathrm{~mol}\right)$ in $1 \mathrm{ml} \mathrm{CCl}$ at room temperature. After the completion of the addition the resulting solution was stirred for $5 \mathrm{~min}$. The solvent was evaporated. The mixture was performed with TLC by eluting with hexane and two products were purified. The first line was the 1,4addition product 14 with $60 \%$ yield. The second line was product 3-bromo-1,2bis(bromomethyl)cyclohex-1-ene (16) as a liquid (4\% isolated yield, $20 \mathrm{mg}$ ). Anal. Calcd for $\mathrm{C}_{8} \mathrm{H}_{11} \mathrm{Br}_{3}$ : C, 27.70; H, 3.20. Found: C, 27.75; H, 3.19.

\section{For 16;}

${ }^{1} \mathrm{H}$ NMR $\left(\mathrm{CDCl}_{3}\right) \delta 5.00(1 \mathrm{H}, \mathrm{bs}), 4.20(1 \mathrm{H}, \mathrm{d}, \mathrm{A}$ part of AB system $J=11.0 \mathrm{~Hz}), 4.10(1 \mathrm{H}, \mathrm{d}, \mathrm{B}$ part of AB system $J=11.0 \mathrm{~Hz}), 4.10(1 \mathrm{H}, \mathrm{d}, \mathrm{A}$ part of AB system $J=10.5 \mathrm{~Hz}), 3.80(1 \mathrm{H}, \mathrm{d}$ B part of AB system $J=10.5 \mathrm{~Hz}), 2.45(1 \mathrm{H}, \mathrm{dd}, J=12.0,5.1 \mathrm{~Hz}), 2.35(2 \mathrm{H}, \mathrm{m}), 1.91(3 \mathrm{H}, \mathrm{m}), 1.76(1 \mathrm{H}, \mathrm{m}) \mathrm{ppm} .{ }^{13} \mathrm{C}$ NMR $\left(\mathrm{CDCl}_{3}\right) \delta: 138.2,134.3,50.6,32.4,30.4,28.8,28.5,17.7 \mathrm{ppm}$. vmax (liquid film): 2959, 2924, 2852, $1461,1428,1338,1188,1061,974,899,825,709,622,532,492$.

\subsubsection{Bromination of 1,2-Dimethylenecyclohexane (1) with 1.1 Equivalent Bromine at $77^{\circ} \mathrm{C}$}

To a magnetically stirred solution of $1\left(310 \mathrm{mg} 2.8710^{-3} \mathrm{~mol}\right)$ in $5 \mathrm{~mL} \mathrm{CCl}_{4}$ was added drop wise to the solution of bromine ( $459 \mathrm{mg}, 2.8710^{-3} \mathrm{~mol}$ ) in $5 \mathrm{ml} \mathrm{CCl}_{4}$ at $77^{\circ} \mathrm{C}$. After the completion of the addition the resulting solution was stirred for $5 \mathrm{~min}$. The solvent was evaporated. ${ }^{1} \mathrm{H}-\mathrm{NMR}$ spectra indicated that the main product was $1470 \%$ and minor products were $18(20 \%)$ and $\mathbf{1 6}(8 \%)$ conversation. To separate the products hexane added in the reaction mixture the 3,6-dibromo-1,2-bis(bromomethyl)cyclohex-1-ene 18 was crystallized as a white color $\left(12 \%\right.$ yield, $184 \mathrm{mg}$, m.p. $\left.128-130{ }^{\circ} \mathrm{C}\right)$. The remaining part after crystallation was separated with hexane on the silica gel colon. It was observed that $\mathbf{1 4}$ in fraction 3-6 and 16 material in fraction 7-8. Anal. Calcd for $\mathrm{C}_{8} \mathrm{H}_{10} \mathrm{Br}_{4}: \mathrm{C}, 22.57 ; \mathrm{H}, 2.37$. Found: $\mathrm{C}, 22.59 ; \mathrm{H}, 2.27$.

For 18;

${ }^{1} \mathrm{H}$ NMR $\left(\mathrm{CDCl}_{3}\right) \delta 5.05(2 \mathrm{H}, \mathrm{CH}-\mathrm{Br}, \mathrm{bs}), 4.13\left(2 \mathrm{H}, \mathrm{CH}_{2}-\mathrm{Br}, \mathrm{d}, \mathrm{A}\right.$ part of AB system $\left.J=11.0 \mathrm{~Hz}\right), 4.05$ $\left(2 \mathrm{H}, \mathrm{CH}_{2}-\mathrm{Br}, \mathrm{d}, \mathrm{B}\right.$ part of AB system $\left.J=11.0 \mathrm{~Hz}\right), 2.42(2 \mathrm{H}, \mathrm{m}), 2.20(2 \mathrm{H}, \mathrm{m}), \mathrm{ppm} .{ }^{13} \mathrm{C}$ NMR $\left(\mathrm{CDCl}_{3}\right)$ $\delta: 136.4,48.8,28.1,28.0$ ppm. vmax (nujol): 2980, 2890, 1410, 1290, 710, 580.

\subsubsection{Bromination of 1,2-Dimethylenecyclohexane (1) with Excess Bromine at Room Temperature}

To a magnetically stirred solution of exocyclic dien $1\left(250 \mathrm{mg} 2.3110^{-3} \mathrm{~mol}\right)$ in $5 \mathrm{~mL} \mathrm{CCI}_{4}$ was added drop wise 5 eqv. of bromine (1.84 g $\left.11.5510^{-3} \mathrm{~mol}\right)$ solution in $1 \mathrm{~mL} \mathrm{CCI}_{4}$ at room temperature. After the completion of the addition the reaction mixture was stirred additional for $5 \mathrm{~min}$. The solvent was removed under reduced pressure. Tetra bromine added product 1,2-dibromo-1,2-bis(bromomethyl)cyclohexane (17) was isolated as a sole product. Recrystallized from pentane, as colorless crystals (92\% yield, $1.14 \mathrm{~g}$, m.p. 92-94 ${ }^{\circ}$ C). Anal. Calcd for $\mathrm{C}_{8} \mathrm{H}_{12} \mathrm{Br}_{4}$ : C, 22.46; H, 2.83. Found: C, 22.51; H, 2.78.

${ }^{1} \mathrm{H}$ NMR $\left(\mathrm{CDCl}_{3}\right) \delta 4.35\left(2 \mathrm{H}\right.$, methylenic $\mathrm{CH}_{2}-\mathrm{Br}$, d, A part of AB system $\left.J=11.5 \mathrm{~Hz}\right), 4.15(2 \mathrm{H}$, methylenic $\mathrm{CH}_{2}-\mathrm{Br}$, d, B part of AB system $\left.J=11.5 \mathrm{~Hz}\right), 2.45\left(2 \mathrm{H}, \mathrm{CH}_{2}, \mathrm{~d}, J=15 \mathrm{~Hz}\right), 2.15\left(2 \mathrm{H}, \mathrm{CH}_{2}, \mathrm{~m}\right)$, $1.78\left(2 \mathrm{H}, \mathrm{CH}_{2}, \mathrm{~m}\right)$, ppm. ${ }^{13} \mathrm{C} \mathrm{NMR}\left(\mathrm{CDCl}_{3}\right) \delta: 75.3,43.9,36.6,22.1 \mathrm{ppm}$. vmax (KBr): 2940, 2921, 2870, $1439,1363,1252,1150,932,861,638,520$.

\subsubsection{Bromination of 1,2-Dimethylenecyclohexane (1) with Excess Bromine at $77^{\circ} \mathrm{C}$}

To a refluxing solutions of 1,2-dimethylenecyclohexane (1) $\left(310 \mathrm{mg} 2.710^{-3} \mathrm{~mol}\right)$ in $5 \mathrm{~mL}$ of $\mathrm{CCl}_{4}$ was added a hot solution of 5 eqv. bromine $\left(2.2 \mathrm{~g} 1.3810^{-2} \mathrm{~mol}\right)$ in $2 \mathrm{~mL} \mathrm{CCl}_{4}$. The resulting mixture was kept at the reflux temperature for $5 \mathrm{~min}$. Then the solvent was removed under vacuum. The crude mass was chromatographed on silica gel eluting with $2 \% \mathrm{CH}_{2} \mathrm{CI}_{2}$-hexane. The compounds 16, 17 and 18, were 
isolated in 7\% (70 mg), 70\% (858 $\mathrm{mg})$ and 10\% (122 mg) yields, respectively.

\subsubsection{Bromination of 1,2-Bis-(bromomethyl)cyclohexene (14) with Excess Bromine at $77^{\circ} \mathrm{C}$}

To a refluxing solution of 1,2-bis-(bromomethyl)cyclohexene (14) (60 $\mathrm{mg} \mathrm{0,224} \mathrm{mmol)} \mathrm{in} 3 \mathrm{~mL}$ of $\mathrm{CCl}_{4}$ was added to the hot solution of 5 eqv. bromine $\left(179 \mathrm{mg} 1.1210^{-3} \mathrm{~mol}\right)$ in $1 \mathrm{~mL} \mathrm{CCI}_{4}$. The resulting mixture was kept at reflux temperature for $5 \mathrm{~min}$. After the completion of the reaction, the solvent was removed under vacuum. The ${ }^{1} \mathrm{H}-\mathrm{NMR}$ spectra were taken the crude product. According to ${ }^{1} \mathrm{H}-\mathrm{NMR}$ spectra product and conversion rates were 3,6-dibromo-1,2-bis(bromomethyl)cyclohex-1-ene (18) 66\% (58 mg; 61\% isolated yield) and 3-dibromo-1,2-bis(bromomethyl)cyclohex-1-ene (16) 34\% (23 mg, 30\% isolated yield), respectively.

\section{CONCLUSIONS}

The bromination reactions of 1,2-dimethylcyclohexane were examined under various reaction conditions and the effect of the reaction temperatures and the amount of the bromine on the product distributions were investigated.

Occurrence of the kinetically controlled 1,2-addition product together with 1,4-adducts at low temperatures were determined by NMR spectroscopy but the 1,2-addition product could not be isolated. It was seen that the increase in temperature caused a decrease in the amount of kinetically controlled product and an increase in the 1,4-addition products together with radicalic addition products. Increasing the amount of bromine produced an increase in the amounts of radicalic addition products and tetrabromo adduct products.

\section{ACKNOWLEDGEMENTS}

The Author is indebted to the TÜBITAK (Project No: TBAG 103T054) for financial support. The author also thanks to Ebru Mete for elemental analysis and especially Prof. Dr. Metin Balc1 for critical scientific review of this manuscript.

\section{CONFLICTS OF INTEREST}

No conflict of interest was declared by the author.

\section{REFERENCES}

[1] Ozer, M. S., Kilbas, B., Balci, M., "High temperature bromination Part XXIII: Bromination of octahydro-1H-indene and octahydro-1H-4,7-methanoindene", ARKIVOC, 4: 388-404, (2013).

[2] Wiclatz, J. E, Short, J. N., 1952, US 26010, 75: 19520617.

[3] Bailey, J. W., Golden, R. H., "Cyclic Dienes. I. 1,2-Dimethlenecyclohexane", J. Am. Chem. Soc., 75: 4780-4782, (1953).

[4] Bailey, J. W., Sorenson, R. W., "Cyclic Dienes.VIII. 1,2-Dimethylenecyclopentane", J.Am. Chem. Soc., 76: 5421-5423, (1954).

[5] Groesbeek M., Van Galen J. J. A., Ippel J.H., Berden J. A., Lugtenburg J., "Three bacteriorhodopsins with ring-didemethylated 6-s-locked chromophores and their properties" Rec. Trav. Chim. Pays-Bas, 112: 237-246, (1993). 
[6] Fujiwara, K., Kurahashi, T., Matsubara, S., "Cationic Iron (III) Porphyrin-Catalyzed [4 + 2] Cycloaddition of Unactivated Aldehydes with Simple Dienes", J. Am. Chem. Soc., 134(12): 5512$5515,(2012)$.

[7] Liang, D., Zou, Y., Wang, Q., Goeke, A., "Sequential Diels-Alder Reaction/Rearrangement Sequence: Synthesis of Functionalized Bicyclo[2.2.1]heptane Derivatives and Revision of Their Relative Configuration”, J. Org. Chem., 79(14): 6726-6731, (2014).

[8] De Lucchi, O., Daştan, A., Altundaş, A., Fabris, F., Balci, M., "Cyclotrimerization of Oxabenzonorbornadiene: Synthesis of syn- and anti-5,6,11,12,17,18-hexahydro-5,18:6,11:12,17triepoxytrinaphthylene", Helv. Chim. Acta, 87(9): 2364-2367, (2004).

[9] Thakur, A., Facer, M. E., Louie, J., "Nickel-Catalyzed Cycloaddition of 1,3-Dienes with 3Azetidinones and 3-Oxetanones", Angew. Chem., Int. Ed., 52(46): 12161-12165, (2013).

[10] Wittig, G., Knaus, E., “Dehydrobenzol und Cyclopentadien”, Chem Berr., 91: 895-907, (1958).

[11] Wilt, J. W., Gutman, G., Raunus W. J. Jr.; Ziegman, A. R., "Studies of benzonorbornene and derivatives. I. Chloro- and bromobenzonorbornenes and related compounds", J. Org. Chem., 32: 893-901, (1967).

[12] Essiz, S., Sengul, M. E., Sahin, E., Dastan, A., "Bromination of 2,3-dihydrobenzobarrelene and synthesis of its mono- and dibromide derivatives: unexpected Wagner-Meerwein rearrangement on silica gel", Turk. J. Chem., 35: 587-598, (2011).

[13] Taskesenlioglu, S., Dastan, A., Dalkilic, E., Guney, M., Abbasoglu, R., "Low and high temperature bromination of 2,3-dicarbomethoxy and 2,3-dicyano benzobarrelene: unexpected substituent effect on bromination", New J. Chem., 34: 141-150, (2010).

[14] Harmandar, M.; Balc1, M., "The Bromination of 3-Bromo -6,7- Benzobicyclo [3.2.1] octa- 2,6diene", Tetrahedron Lett., 26: 5465-5468, (1985).

[15] Daştan, A., Balc1, M., Hökelek, T., Ülkü, D., Büyükgüngör, O., "High temperature bromination VI: Bromination of benzobarrelene", Tetrahedron, 50: 10555-10578, (1994).

[16] Dastan, A., Tasgesenligil, Y., Tümer, F., Balci, M., "High temperature bromination VIII: Bromination of homobenzonorbornadiene", Tetrahedron, 52: 14005-14020, (1996).

[17] Altundaş, A., Daştan, A., McKee, M. M., Balci, M., "High Temperature Bromination. Part 12:1 Bromination of 7-Oxabenzonorbornadiene: Synthesis of 2,3-Dibromo-7-oxabenzonorbornadiene", Tetrahedron, 56: 6115-6120, (2000).

[18] March, J. Advanced Organic Chemistry; Wiley: New York, (1991).

[19] Horasan, N.,Kara, Y., Azizoğlu, A., Balc1, M., "Low and high temperature bromination of exocyclic dienes: high temperature bromination. Part 16", Tetrahedron, 59: 3691-3699, (2003).

[20] Jahn, R., Schmidt, U., "Lichtreaktionen mit Carbonsäurederivaten, IX. Abfangversuche mit photochemisch erzeugtem monoatomarem und diatomarem Schwefel. Schwefeladdition an 1, 2Dimethylencyclohexan. - Synthese von 1,4,5,6,7,8-Hexahydrobenzo[d][1,2]dithiin und 1,3,4,5,6,7Hexahydrobenzo[c]thiophen", Chem.Ber., 108: 630-639, (1975). 